\title{
Does the antidepressant-like effect of mirtazapine and venlafaxine differ between male and female rats?
}

\author{
Adriana Álvarez Silva, 'Alonso Fernández-Guasti’
}

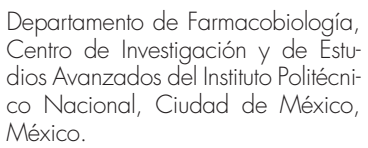

Correspondence:

Alonso Fernández-Guasti

Laboratorio de Farmacología

Conductual, Centro de Investigación

y de Estudios Avanzados del Instituto

Politécnico Nacional.

Calzada de los Tenorios 235

Col Granjas Coapa,

Alcaldía Tlalpan

14330. Ciudad de México México.

Phone: +52 (55) 5483 - 2848

Email: jfernand@cinvestav.mx

Received: 7 August 2019

Accepted: 14 November 2019

Citation:

Álvarez Silva, A., \& Fernández-Guasti,

A. (2020). Does the antidepressant-like

effect of mirtazapine and venlafaxine

differ between male and female rats?

Salud Mental, 43(1), 3-9.

DOI: $10.17711 /$ SM.0185-3325.2020.002

\begin{abstract}
Introduction. Depression is a global health problem with nearly 350 million people affected, mainly women. However, nowadays a rising amount of men are being diagnosed. This makes necessary the screening of new treatment options that are effective in women as well as in men. Objective. To analyze if the administration of mirtazapine and venlafaxine to male and female rats shows a sex-related antidepressant-like effect, and the possible associated neurochemical mechanisms. Method. Mirtazapine $(40 \mathrm{mg} / \mathrm{kg})$ or venlafaxine $(60 \mathrm{mg} / \mathrm{kg})$ were administered subchronically to young adult male and female (ovariectomized and steroid-primed) rats, and their antidepressant-like effects were evaluated using the forced swim test (FST). The active behaviors, swimming and climbing, were also analyzed. Results. a) mirtazapine and venlafaxine reduced immobility in the FST in males and females; b) both antidepressants increased climbing and swimming in male rats; c) in female rats, mirtazapine and venlafaxine only increased swimming. Discussion and conclusion. In males, the effects of mirtazapine and venlafaxine seem to be produced by the activation of the serotonergic and noradrenergic systems. Conversely, estradiol might be modulating the mechanisms of action of both antidepressants in females producing only an increased swimming and suggesting the participation of the serotonergic system.
\end{abstract}

Keywords: Mirtazapine, venlafaxine, antidepressants, sex differences, forced swim test.

\section{RESUMEN}

Introducción. La depresión es un trastorno psiquiátrico que representa un problema de salud mundial. Afecta a cerca de 350 millones de personas, predominantemente mujeres. Sin embargo, algunos reportes indican que su incidencia en hombres está aumentando, por lo que es necesario buscar opciones de tratamiento que sean igualmente efectivas en ambos sexos. Objetivo. Analizar si existen diferencias relacionadas con el sexo en el efecto de tipo antidepresivo de la mirtazapina y la venlafaxina, y considerar los posibles mecanismos neuroquímicos involucrados. Método. se administraron mirtazapina $(40 \mathrm{mg} / \mathrm{kg})$ o venlafaxina $(60 \mathrm{mg} / \mathrm{kg})$ en esquema subcrónico a grupos independientes de ratas macho y hembra ovariectomizadas tratadas con estradiol y progesterona. Se evaluaron el efecto tipo antidepresivo y las conductas activas (nado y escalamiento) utilizando la prueba de nado forzado (PNF). Resultados. a) tanto la mirtazapina como la venlafaxina redujeron la inmovilidad en la PNF en machos y hembras; b) ambos antidepresivos incrementaron las conductas activas en machos; c) en hembras, la mirtazapina y la venlafaxina produjeron un aumento del nado, pero no modificaron el escalamiento. Discusión y conclusión. En machos, los efectos de la mirtazapina y la venlafaxina en la PNF se deben a su acción sobre los sistemas serotonérgico y noradrenérgico; en cambio, en hembras sólo se modifica la conducta de nado, lo que sugiere que el estradiol modula las acciones de ambos antidepresivos sobre el sistema serotoninérgico.

Palabras clave: Mirtazapina, venlafaxina, antidepresivos, diferencias de sexo, prueba de nado forzado. 


\section{INTRODUCTION}

Depression is a common affective disorder which affects approximately $4 \%$ of the world population (World Health Organization [WHO], 2018). It is characterized by low mood and anhedonia, and in the worst cases it can lead to suicide. Although most studies report that the incidence of depression is greater in women than in men (by nearly $2: 1$ ), there is evidence that this gap might be narrowing (Addis, 2008). Also, some of the most severe consequences of depression, as drug abuse and suicide, are far more frequent in men than in women (Cochran \& Rabinowitz, 2000).

Currently, multiple therapeutic options for depression are available. However, many studies have shown that there is a gender-related difference in the response to some antidepressants (Berlanga \& Flores-Ramos, 2006; Kornstein et al., 2000; Šagud, Hotujac, Milhaljević-Pelleš, \& Jakovljević 2002). For example, women seem to tolerate and respond better to selective serotonin reuptake inhibitors (SSRIs) (Martenyi, Dossenbach, Mraz, \& Metcalfe, 2001; Sramek, Murphy, \& Cutler, 2016) than to noradrenaline reuptake inhibitors (NRIs). On the other hand, men show improvement with both SSRIs and NRIs (Berlanga \& Flores Ramos, 2006), but also respond well to tricyclic antidepressants (Kornstein et al., 2000).

Some antidepressants like venlafaxine and the atypical antidepressant, mirtazapine, exert their actions on the noradrenergic and serotonergic systems. Venlafaxine is a serotonin and noradrenaline reuptake inhibitor (SNRI) (Holliday \& Benfield, 1995). Mirtazapine's main mechanism of action is through the antagonism of $\alpha 2$-adrenergic auto- and heteroreceptors, as well as the blockade of $5-\mathrm{HT}_{2}$ and $5-\mathrm{HT}_{3}$ serotonin receptors, which enhance the release of serotonin and noradrenaline, and favors the 5-HT $\mathrm{HA}_{1 \mathrm{~A}}$-mediated serotonergic neurotransmission (Anttila \& Leinonen, 2001). The dual action of these antidepressants makes them suitable for the treatment of depression in both, men and women.

Previous studies have reported that venlafaxine has a greater effect in male than in female rats in the chronic mild stress model of depression, through the measurement of sucrose consumption (Xing et al., 2013), and in the open field test, that evaluates experimental anxiety (Gray \& Hughes, 2015). However, there are no reports on putative sex differences using the forced swim test (FST), which is a common test for the screening of drugs with antidepressant properties and permits to suggest putative mechanisms of action. Thus, in the FST, the administration of noradrenergic or dopaminergic drugs reduce immobility at an expense of enhancing climbing, while drugs that promote serotonergic neurotransmission also reduce immobility but increase swimming behavior (Bogdanova, Kanekar, D’Ancy, \& Renshaw, 2013; Detke, Rickels, \& Lucki, 1995).
In this study, intact male and ovariectomized steroid-primed female rats were used. This design was purposed to ensure that all females were in the same hormonal state (induced proestrus) during the antidepressant treatment, and to observe the potential influence of gonadal hormones on the antidepressant-like effect, given that male rats were intact. In the FST, under basal conditions, females in proestrus exhibit less immobility than those in metestrus-diestrus (Estrada-Camarena, López-Rubalcava, Hernández-Aragón, Mejía-Mauries, \& Picazo, 2011) or ovariectomized ones (Vega-Rivera, Fernández-Guasti, Ramírez-Rodríguez, \& Estrada-Camarena, 2013a). Furthermore, the antidepressant responses also vary depending on the phase of the rat's estrous cycle (Barros \& Ferigolo, 1998).

\section{METHOD}

\section{Design of the study}

A quantitative, preclinical cross-sectional, controlled, and comparative study was performed.

\section{Subjects}

Young adult male (250-350 g) and female (180-250 g) Wistar rats were used in this study. All animals were provided by the vivarium of our research center (CINVESTAV), and kept in controlled conditions of temperature $\left(23^{\circ} \mathrm{C}\right)$ on a $12-\mathrm{h} / 12$-h inverted light-dark cycle, with lights on at 22:00 hrs. The animals were kept in groups of seven-eight per cage (each cage measuring $44 \mathrm{~cm}$ width $\times 33 \mathrm{~cm}$ length $\times 20 \mathrm{~cm}$ height), with ad libitum access to water and commercial rat chow.

Female rats were anesthetized with tribromoethanol 2\% at a dose of $1 \mathrm{ml} / \mathrm{kg}$, and bilaterally ovariectomized (OVX). After surgery, the rats were kept for recovery for thirteen days. Past these days, the rats were hormonally primed with $10 \mu \mathrm{g}$ estradiol benzoate, and 20 hours later with $3 \mathrm{mg}$ progesterone (Hernández-Munive, Rebolledo-Solleiro, Ventura-Aquino, \& Fernández-Guasti, 2018). Hormones were dissolved in corn oil and administered subcutaneously in a volume of $.3 \mathrm{ml} / \mathrm{rat}$. The tests were made 24 hours after the administration of estradiol benzoate, and four hours after the administration of progesterone.

\section{Measurements}

To compare the antidepressant-like effect of mirtazapine and venlafaxine among male and female rats, the same antidepressants doses were used in both sexes. Mirtazapine was administered at $40 \mathrm{mg} / \mathrm{kg}$, while the dose of venlafaxine was $60 \mathrm{mg} / \mathrm{kg}$. These doses were chosen according to previous experiments (Álvarez-Silva \& Fernández-Guas- 
ti, 2019). Motor coordination and general activity were evaluated prior to the FST.

\section{Procedures}

Mirtazapine (MTZ) was dissolved in physiological saline with $.5 \%$ acetic acid. Venlafaxine (VLF) hydrochloride was dissolved in physiological saline. Both drugs were administered intraperitoneally using a subchronic schedule $(23,5$, and 1 hour before the evaluation) in a volume of $4 \mathrm{ml} / \mathrm{kg}$. The subchronic scheme was chosen based on previous results (Detke et al., 1995; Hernández \& Fernández-Guasti, 2018; Rénéric, Bouvard, \& Stinus, 2002; Álvarez-Silva \& Fernández-Guasti, 2019). All the experiments were performed during the first four hours of the awake phase of the animals.

\section{Forced swim test}

Forced swimming is a widely used test for the evaluation of antidepressants. This test is based on the observation that rats, when placed in a cylinder with water and forced to swim, eventually make only the minimal movements necessary to keep their heads above the water level, a behavior known as immobility. The use of the FST as a model of depression has been controverted by the suggestion that it might reflect learning rather than despair (Molendijk \& de Kloet, 2015). However, it is still considered an appropriate test to assess the potential antidepressant-like effect of drugs (Slattery \& Cryan, 2012).

The procedure consisted in placing the rats in individual glass cylinders $(45 \mathrm{~cm}$ tall $\times 20 \mathrm{~cm}$ diameter $)$ that had been filled with water $30 \mathrm{~cm}$ deep (Detke et al., 1995). Two swimming sessions were conducted: a 15-minute pretest, followed 24 hours later by a 5-minute test. Antidepressant treatments were administered between these sessions. After each ses-

\section{A}

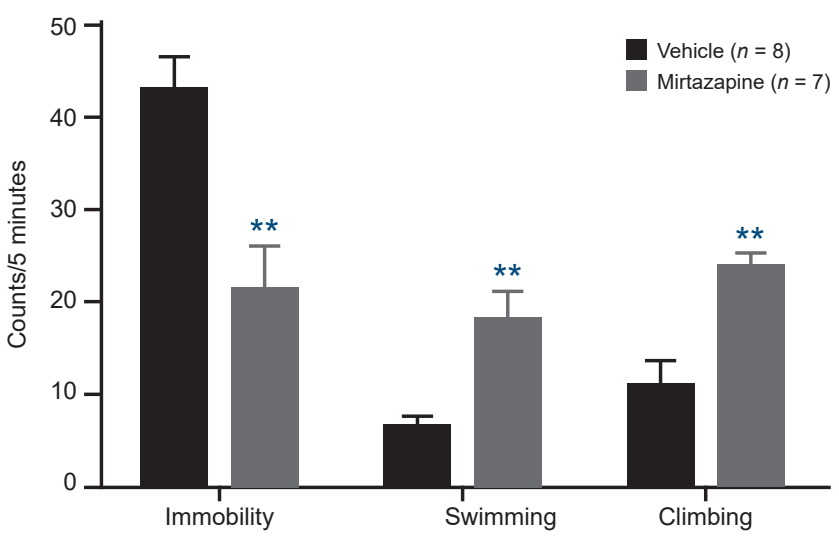

sion, rats were removed from the cylinders, dried with towels, placed in warm cages, and later returned to their home cages. Test sessions were videotaped for later scoring of three different behaviors: immobility (passive behavior), swimming, and climbing (active behaviors). The actions were scored after a 5 -seconds period, so 60 counts were obtained over the 5-minute test sessions (Estrada-Camarena, Rivera, Berlanga, \& Fernández-Guasti, 2008; Hernández \& Fernández-Guasti, 2018; Álvarez-Silva \& Fernández-Guasti, 2019).

\section{Rota Rod test}

To assess possible motor coordination effects of drug treatments, all groups evaluated in the FST were tested in the Rota Rod. This test consisted in placing the rats on a rotating cylinder at a constant speed of 11 rotations/minute. The animals were subjected to two training sessions in consecutive days before the test. The final evaluation was made right before the FST and the total of drop-offs in a period of five minutes were counted for each rat.

\section{Open-field test}

Locomotor activity was measured individually using an actimeter (Panlab LE 8825), that consisted in a polypropylene box $(45 \times 45 \times 20 \mathrm{~cm})$ with two infrared frames. The rat was placed in the center of the box, left for five minutes, and the counts of general activity, stereotyped movements and rearings were obtained. At the end of each individual test, the box was cleaned with $70 \%$ alcohol.

\section{Statistical analysis}

Data are presented as means \pm standard errors. Differences were considered statistically significant when the $p$ value was $\leq .05$. The comparisons between control and treated animals were made using the Mann-Whitney U test.



Figure 1. Effect of mirtazapine $40 \mathrm{mg} / \mathrm{kg}(\mathrm{A})$ and venlafaxine $60 \mathrm{mg} / \mathrm{kg}(\mathrm{B})$ in the FST on male rats. Values are presented as mean ( \pm SEM) counts of immobility, swimming, and climbing behaviors assessed every 5 s during the 5 -minute test. Data were analyzed using the Mann-Whitney U test. ${ }^{* *} p<.01$ vs. control group. 
A

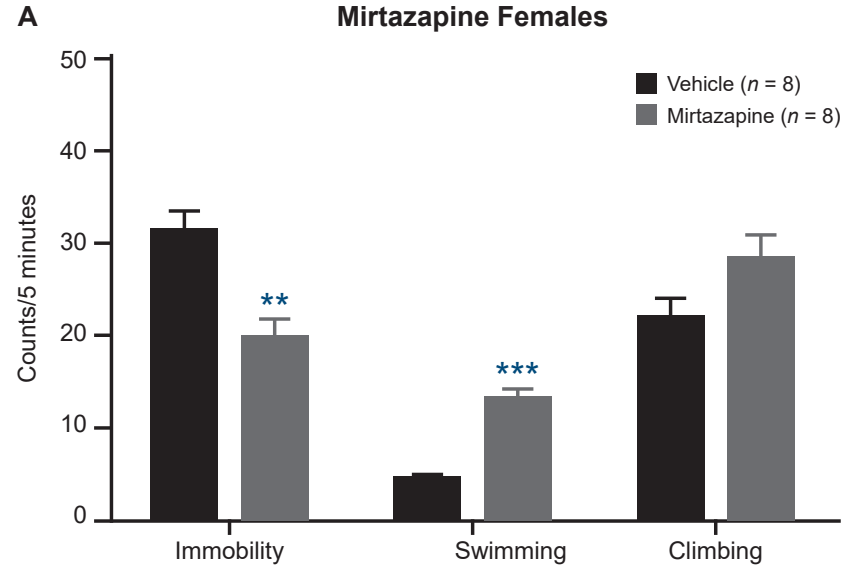

B

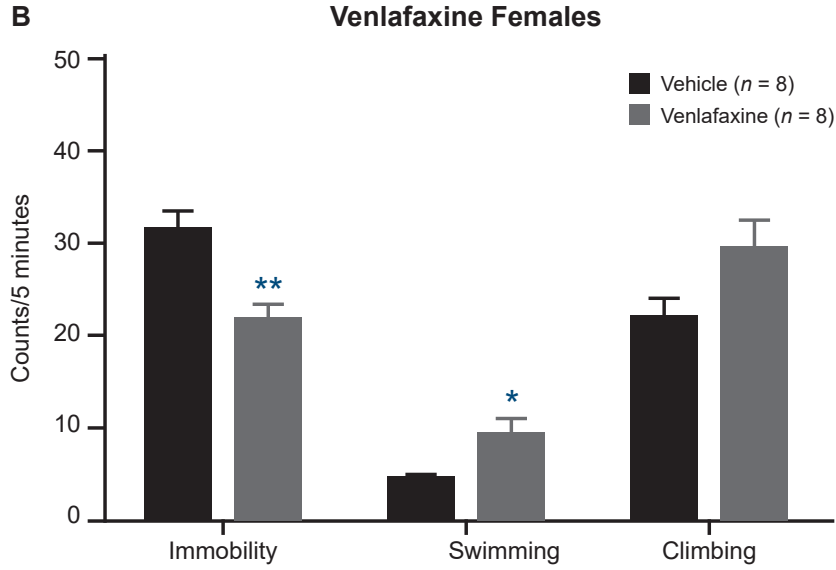

Figure 2. Effect of mirtazapine $40 \mathrm{mg} / \mathrm{kg}(\mathrm{A})$ and venlafaxine $60 \mathrm{mg} / \mathrm{kg}(\mathrm{B})$ in the $\mathrm{FST}$ on female rats. Values are presented as mean $( \pm$ SEM) counts of immobility, swimming, and climbing behaviors assessed every 5 s during the 5 -minute test. Data were analyzed using the Mann-Whitney $U$ test. ${ }^{*} p<.05 ;{ }^{* *} p<.01 ;{ }^{* * *} p<.001$ vs. control group.

\section{Ethical considerations}

All experimental procedures were performed in accordance with the Mexican Official Norm for animal care and handling (NOM-062-ZOO-1999) and approved by the Institutional Ethics Committee of the CINVESTAV-IPN.

\section{RESULTS}

The effect of mirtazapine on immobility, swimming, and climbing on male rats is shown in Figure 1A. Mirtazapine produced a significant decrease in immobility $(U=4.5$, $p=.004)$, with an increase of both swimming ( $U=3.5$, $p=.002)$, and climbing $(U=5.5, p=.006)$. Figure 1B shows that venlafaxine administration to males also reduced immobility $(U=3.5, p=.002)$ and significantly increased both active behaviors (swimming: $U=6, p=.008$; climbing: $U=5.5, p=.006$ ).

In female rats, mirtazapine also reduced immobility $(U$ $=6, p=.004)$ and increased swimming $(U=0, p=.0002)$, but not climbing behavior $(U=17$, ns) (Figure 2A). Venlafaxine showed a similar profile, reducing immobility $(U=7.5$, $p=.004)$ with an increased swimming $(U=9.5, p=.017)$,

Table 1

Locomotor activity after the administration of mirtazapine or venlafaxine in male and female rats

\begin{tabular}{lcc}
\hline Treatment & Males & \multicolumn{2}{c}{ Females } \\
\hline Vehicle & $1714 \pm 325$ & $1818 \pm 440$ \\
Mirtazapine $40 \mathrm{mg} / \mathrm{kg}$ & $401 \pm 98^{\star * *}$ & $327.5 \pm 159^{* * *}$ \\
Venlafaxine $60 \mathrm{mg} / \mathrm{kg}$ & $1462 \pm 287$ & $1192 \pm 413$ \\
\hline
\end{tabular}

Values represent mean number of counts \pm SEM. Data were analyzed using the Mann-Whitney U test. ${ }^{* *} p<.001$ vs. control group. but with no significant increases in climbing $(U=14, \mathrm{~ns})$ (Figure 2B).

Regarding locomotor activity, mirtazapine reduced spontaneous activity in both male and female rats. On the other hand, venlafaxine did not affect locomotion (Table 1). Neither mirtazapine nor venlafaxine modified the number of drops from the Rota Rod (data not shown).

\section{DISCUSSION AND CONCLUSION}

In this study, we analyzed the antidepressant-like effect of mirtazapine and venlafaxine on male and female rats using the FST. The main findings were:

- Both antidepressants similarly reduced immobility in male and female rats.

- In males, mirtazapine and venlafaxine increased both active behaviors, whereas in females these antidepressants enhanced only swimming.

- Mirtazapine reduced locomotor activity in both sexes, while venlafaxine had no effect.

The antidepressant-like effect of mirtazapine in male rats was reported in previous studies (Rénéric et al., 2002; Rogóz, Kabzị̄ski, Sadaj, Rachwalska, \& Gadek-Michalska, 2012). Our results agree with those reported by Rénéric et al. (2002) showing that subchronic mirtazapine reduced immobility at an expense of increasing both swimming and climbing. It is known that mirtazapine, through the $\alpha 2$-adrenergic receptor blockade (de Boer, Ruigt, \& Berendsen, 1995; de Montigny, Haddjeri, Mongeau, \& Blier, 1995), increases the serotonergic and noradrenergic neurotransmission. The enhancement of both neurotransmission systems may produce greater antidepressant-like effects than those produced by selective antidepressants (Rénéric et al., 
2002). The negative effect of mirtazapine on locomotor activity may be produced by its high affinity for histaminergic H1 receptors, which activation induces sedation (Davis \& Wilde, 1996). However, this effect did not interfere with the increase in active behaviors seen in the FST nor with the motor coordination tested in the Rota Rod.

Venlafaxine is a dual reuptake inhibitor, five times more potent to inhibit serotonin reuptake than noradrenaline reuptake (Holliday \& Benfield, 1995). However, at high doses, venlafaxine may also inhibit dopamine reuptake (Rénéric \& Lucki, 1998). Accordingly, Rénéric \& Lucki (1998) using the rat FST, found that low doses of venlafaxine $(10,20$ and 40 $\mathrm{mg} / \mathrm{kg})$ enhanced swimming, while higher doses $(80 \mathrm{mg} / \mathrm{kg})$ also increased climbing. Present results showing that $60 \mathrm{mg} /$ $\mathrm{kg}$ of venlafaxine in males reduced immobility at an expense of increasing swimming and climbing agree with these data. Furthermore, Millan et al. (2001) showed that venlafaxine at doses higher than $40 \mathrm{mg} / \mathrm{kg}$ increased the concentrations of serotonin and noradrenaline in the brain frontal cortex up to four to six times compared with lower doses. As shown, the venlafaxine dose here used $(60 \mathrm{mg} / \mathrm{kg})$ reduced immobility without altering locomotion, suggesting that its effect may be considered as selective antidepressant-like.

The present result shows that mirtazapine in female rats reduced immobility and increased swimming agrees with the report of Melo et al. (2012), who showed that this antidepressant did not increase climbing in this sex. However, these findings contrast with the report of Rénéric \& Lucki (1998) using the same dose in males, stressing the importance of sex and possibly of gonadal hormones in the neurochemical effects of mirtazapine and other antidepressants (Estrada-Camarena, Fernández-Guasti, \& López-Rubalcava, 2003; Vega-Rivera, López-Rubalcava, \& Estrada-Camarena, 2013b).

The antidepressant-like effect of venlafaxine in the FST in female rats agrees with the report of Estrada-Camarena et al. (2008). In that and in the present study, the co-administration of venlafaxine and estradiol to OVX rats reduced immobility and increased swimming, without modifying climbing. These results suggest that the presence of estradiol may increase the sensitivity to the serotonergic actions of venlafaxine in female rats.

The results of this study suggest that estrogens favor in females the serotonergic actions of both mirtazapine and venlafaxine. There are several mechanisms by which estradiol regulates the serotonergic system. For example, estradiol inhibits SERT (Bertrand et al., 2005; Koldzic-Zivanovic, Seitz, Watson, Cunningham, \& Thomas, 2004), increases the serotonin synthesis, and promotes the desensitization of 5- $\mathrm{HT}_{1 \mathrm{~A}}$ receptors (Vega-Rivera et al., 2013b), and induces the uncoupling of the 5- $\mathrm{HT}_{1 \mathrm{~A}}$ receptor from its $\mathrm{G}$ protein (Mize, Young, \& Alper, 2003). These actions enhance the serotonergic transmission that might underlie the effects of mirtazapine and venlafaxine on swimming.
In addition to the prevalent action of the serotonergic transmission in females, it must be considered that males have a higher catecholamine response after the administration of idazoxan (an $\alpha 2$-adrenergic blocker) in comparison to females (Schmidt et al., 1997). Such sex difference may explain why mirtazapine and venlafaxine increased climbing in males.

It is important to highlight that, without any antidepressant treatment, male rats showed a higher number of immobility counts than females, and this difference was statistically significant $(U=11, p=.02)$. This was one of the reasons why a 2-way ANOVA was not performed (the other reason was that not all data followed a normal distribution). This sex difference in immobility has been previously reported (Fernández-Guasti, Olivares-Nazario, Reyes, \& Martínez-Mota, 2017; Gómez, Martínez-Mota, Estrada-Camarena, \& Fernández-Guasti, 2014; Kokras et al., 2009) and may respond to sex variations in dopamine (Dalla et al., 2008), serotonin (Dalla, Pitychoutis, Kokras, \& Papadopoulou-Daifoti, 2010), and 5-HT $\mathrm{HA}_{1 \mathrm{~A}}$ receptors (Drossopoulou et al., 2004) in brain areas that modulate stress-related behaviors. These differences may also explain the higher sensitive serotonergic system (primarily to external factors) in women as compared to men (Khan, Brodhead, Schwartz, Kolts, \& Brown, 2005).

In conclusion, mirtazapine and venlafaxine showed a similar antidepressant-like effect in both male and female rats. However, both antidepressants increased swimming and climbing behaviors in males, while in female rats, only swimming was enhanced, suggesting the sex differential participation of noradrenaline and serotonin.

\section{Funding}

This research was supported by a fellowship from CONACyT (No. 456306).

\section{Conflict of interest}

The authors declare they have no conflicts of interest.

\section{Acknowledgments}

We thank Dr. Jorge Ocampo from "Laboratorios Bioquimed, México" for mirtazapine and venlafaxine donation.

\section{REFERENCES}

Addis, M. E. (2008). Gender and depression in men. Clinical Psychology: Science and Practice, 15(3), 153-168. doi: 10.1111/j.1468-2850.2008.00125.x

Álvarez-Silva, A. A., \& Fernández-Guasti, A. (2019). The combination of mirtazapine plus venlafaxine reduces immobility in the forced swim test and does not inhibit female sexual behavior. Pharmacology, Biochemistry and Behavior, 187, 172817 doi: $10.1016 /$ j.pbb.2019.172817

Anttila, S. A., \& Leinonen, E. V. (2001). A review of the pharmacological and clinical profile of mirtazapine. CNS Drug Reviews, 7(3), 249-264. doi: 10.1111/j.15273458.2001.tb00198.x 
Barros, H. M., \& Ferigolo, M. (1998). Ethopharmacology of imipramine in the forced swimming test: gender differences. Neuroscience \& Biobehavioral Reviews, 23(2), 279-286. doi: 10.1016/S0149-7634(98)00029-3

Berlanga, C., \& Flores-Ramos, M. (2006). Different gender responses to serotonergic and noradrenergic antidepressants. A comparative study of the efficacy of citalopram and reboxetine. Journal of Affective Disorders, 95(1-3), 119-123. doi: 10.1016/j.jad.2006.04.029

Bertrand, P. P., Paranavitane, U. T., Chavez, C., Gogos, A., Jones, M., \& van den Buuse, M. (2005). The effect of low estrogen state on serotonin transporter function in mouse hippocampus: a behavioral and electrochemical study. Brain Research, 1064(1-2), 10-20. doi: 10.1016/j.brainres.2005.10.018

de Boer, T., Ruigt, G. S. F., \& Berendsen, H. H. G. (1995). The $\alpha 2$-selective adrenoceptor antagonist org 3770 (mirtazapine, Remeron ${ }^{\circledR}$ ) enhances noradrenergic and serotonergic transmission. Human Psychopharmacology: Clinical and Experimental, 10(S2), S107-S118. doi: 10.1002/hup.470100805

Bogdanova, O. V., Kanekar, S., D’Ancy, K. E., \& Renshaw, P. F. (2013). Factors influencing behavior in the forced swim test. Physiology and Behavior, 118, 227-239. doi: 10.1016/j.physbeh.2013.05.012

Cochran, S. V., \& Rabinowitz, F. E. (2000). Men and depression: Clinical and empirical perspectives. San Diego, California: Academic Press. ISBN 0-12177540-2

Dalla, C., Antoniou, K., Kokras, N., Drossopoulou, G., Papathanasiou, G., Bekris, S., ... Papadopoulou-Daifoti, Z. (2008). Sex differences in the effects of two stress paradigms on dopaminergic neurotransmission. Physiology \& Behavior, 93(3), 595-605. doi: 10.1016/j.physbeh.2007.10.020

Dalla, C., Pitychoutis, P. M., Kokras, N., \& Papadopoulou-Daifoti, Z. (2010). Sex differences in animal models of depression and antidepressant response. Basic \& Clinical Pharmacology \& Toxicology, 106(3), 226-233. doi: 10.1111/j.17427843.2009.00516.x

Davis, R., \& Wilde, M. I. (1996). Mirtazapine: A review of its pharmacology and therapeutic potential in the management of major depression. CNS Drugs, 5(5), 389-402. doi: 10.2165/00023210-199605050-00007

Detke, M. J., Rickels, M., \& Lucki, I. (1995). Active behaviors in the rat forced swimming test differentially produced by serotonergic and noradrenergic antidepressants. Psychopharmacology, 121(1), 66-72. doi: 10.1007/ BF02245592

Drossopoulou, G., Antoniou, K., Kitraki, E., Papathanasiou, G., Papalexi, E., Dalla, C., \& Papadopoulou-Daifoti, Z. (2004). Sex differences in behavioral, neurochemical and neuroendocrine effects induced by the forced swim test in rats. Neuroscience, 126(4), 849-857. doi: 10.1016/j.neuroscience.2004.04.044

Estrada-Camarena, E., Fernández-Guasti, A., \& López-Rubalcava, C. (2003). Antidepressant-like effect of different estrogenic compounds in the forced swimming test. Neuropsychopharmacology, 28(5), 830-838. doi: 10.1038/ sj.npp. 1300097

Estrada-Camarena, E., Rivera, N. V., Berlanga, C., \& Fernández-Guasti, A. (2008). Reduction in the latency of action of antidepressants by $17-\beta$ estradiol in the forced swimming test. Psychopharmacology, 201(3), 351-360. doi: 10.1007/ s00213-008-1291-8

Estrada-Camarena, E., López-Rubalcava, C., Hernández-Aragón, A., MejíaMauries, S., \& Picazo, O. (2011). Long-term ovariectomy modulates the antidepressant-like action of estrogens, but not of antidepressants. Journal of Psychopharmacology, 25(10), 1365-1377. doi: 10.1177/0269881111408456

Fernández-Guasti, A., Olivares-Nazario, M., Reyes, R., \& Martínez-Mota, L. (2017). Sex and age differences in the antidepressant-like effect of fluoxetine in the forced swim test. Pharmacology, Biochemistry and Behavior, 152, 81-89. doi: 10.1016/j.pbb.2016.01.011

Gómez, M. L., Martinez-Mota, L., Estrada-Camarena, E., \& Fernandez-Guasti, A. (2014). Influence of the brain sexual differentiation process on despair and antidepressant-like effect of fluoxetine in the rat forced swim test. Neuroscience, 261, 11-22. doi: 10.1016/j.neuroscience.2013.12.035

Gray, V. C., \& Hughes, R. N. (2015). Drug-, dose- and sex-dependent effects of chronic fluoxetine, reboxetine and venlafaxine on open-field behavior and spatial memory in rats. Behavioural Brain Research, 281, 43-54. doi: 10.1016/j. bbr.2014.12.023

Hernández, A., \& Fernández-Guasti, A. (2018). Male rats with same-sex preference show higher immobility in the forced swim test, but similar effects of fluoxetine and desipramine than males that prefer females. Pharmacology, Biochemistry and Behavior, 171, 39-45. doi: 10.1016/j.pbb.2018.05.017

Hernández-Munive, A. K., Rebolledo-Solleiro, D., Ventura-Aquino, E., \& FernándezGuasti, A. (2018). Reduced lordosis and enhanced aggression in paced and nonpaced mating in diabetic female rats. The Journal of Sexual Medicine, 15(2), 124-135. doi: 10.1016/j.jsxm.2017.11.018

Holliday, S. M., \& Benfield, P. (1995). Venlafaxine: A review of its pharmacology and therapeutic potential in depression. Drugs, 49(2), 280-294. doi: 10.2165/00003495-199549020-00010

Khan, A., Brodhead, A. E., Schwartz, K. A., Kolts, R. L., \& Brown, W. A. (2005). Sex differences in antidepressant response in recent antidepressant clinical trials. Journal of Clinical Psychopharmacology, 25(4), 318-324. doi: 10.1097/01. jcp.0000168879.03169.ce

Kokras, N., Antoniou, K., Dalla, C., Bekris, S., Xagoraris, M., Ovestreet, D. H., \& Papadopoulou-Daifoti, Z. (2009). Sex-related differential response to clomipramine treatment in a rat model of depression. Journal of Psychopharmacology, 23(8), 945-956. doi: 10.1177/0269881108095914

Koldzic-Zivanovic, N., Seitz, P. K., Watson, C. S., Cunningham, K. A., \& Thomas, M. L. (2004). Intracellular signaling involved in estrogen regulation of serotonin reuptake. Molecular and Cellular Endocrinology, 226(1-2), 33-42. doi: 10.1016/j.mce.2004.07.017

Kornstein, S. G., Schatzberg, A. F., Thase, M. E., Yonkers, K. A., McCullough, J. P., Keitner, G. I., ... Keller, M. B. (2000). Gender differences in treatment response to sertraline versus imipramine in chronic depression. American Journal of Psychiatry, 157(9), 1445-1452. doi: 10.1176/appi.ajp.157.9.1445

Martenyi, F., Dossenbach, M., Mraz, K., \& Metcalfe, S. (2001). Gender differences in the efficacy of fluoxetine and maprotiline in depressed patients: a doubleblind trial of antidepressants with serotonergic or norepinephrinergic reuptake inhibition profile. European Neuropsychopharmacology, 11(3), 227-232. doi: 10.1016/S0924-977X(01)00089-X

Melo, T. G., Izídio, G. S., Ferreira, L. S., Sousa, D. S., Macedo, P. T., Cabral, A., ... Silva, R. H. (2012). Antidepressants differentially modify the extinction of an aversive memory task in female rats. Progress in Neuro-psychopharmacology and Biological Psychiatry, 37(1), 33-40. doi: 10.1016/j.pnpbp.2012.01.012

Millan, M. J., Gobert, A., Lejeune, F., Newman-Tancredi, A., Rivet, J. M., Auclair, A., \& Peglion, J. L. (2001). S33005, a novel ligand at both serotonin and norepinephrine transporters: I. Receptor binding, electrophysiological, and neurochemical profile in comparison with venlafaxine, reboxetine, citalopram, and clomipramine. Journal of Pharmacology and Experimental Therapeutics, 298(2), 565-580.

Mize, A. L., Young, L. J., \& Alper, R. H. (2003). Uncoupling of 5-HT1A receptors in the brain by estrogens: regional variations in antagonism by ICI 182,780 . Neuropharmacology, 44(5), 584-591. doi: 10.1016/S0028-3908(03)00044-3

Molendijk, M. L., \& de Kloet E. R. (2015). Immobility in the forced swim test is adaptative and does not reflect depression. Psychoneuroendocrinology, 62, 389391. doi: 10.1016/j.psyneuen.2015.08.028

de Montigny, C., Haddjeri, N., Mongeau, R., \& Blier, P. (1995). The effects of mirtazapine on the interactions between central noradrenergic and serotonergic systems. CNS Drugs, 4(1), 13-17. doi: 10.2165/00023210-199500041-00004

Rénéric, J. P., \& Lucki, I. (1998). Antidepressant behavioral effects by dual inhibition of monoamine reuptake in the rat forced swimming test. Psychopharmacology, 136(2), 190-197. doi: 10.1007/s002130050555

Rénéric, J. P., Bouvard, M., \& Stinus, L. (2002). In the rat forced swimming test, NAsystem mediated interactions may prevent the 5-HT properties of some subacute antidepressant treatments being expressed. European Neuropsychopharmacology, 12(2), 159-171. doi: 10.1016/S0924-977X(02)00007-X

Rogóz, Z., Kabzị̄zki, M., Sadaj, W., Rachwalska, P., \& Gądek-Michalska, A. (2012). Effect of co-treatment with fluoxetine or mirtazapine and risperidone on the 
active behaviors and plasma corticosterone concentration in rats subjected to the forced swim test. Pharmacological Reports, 64(6), 1391-1399. doi: 10.1016/ S1734-1140(12)70936-2

Šagud, M., Hotujac, L. J., Mihaljević-Pelleš, A., \& Jakovljević, M. (2002). Gender differences in depression. Collegium Antropologicum, 26(1), 149-157.

Schmidt, M. E., Matochik, J. A., Goldstein, D. S., Schauten, J. L., Zametkin, A. J., \& Potter, W. Z. (1997). Gender differences in brain metabolic and plasma catecholamine responses to alphaz-adrenoceptor blockade. Neuropsychopharmacology, 16(4), 298-310. doi: 10.1016/S0893133X(96)00264-3

Slattery, D. A., \& Cryan, J. F. (2012). Using the rat forced swim test to assess antidepressant-like activity in rodents. Nature Protocols, 7(6), 1009-1014. doi: 10.1038/nprot.2012.044

Sramek, J. J., Murphy, M. F., \& Cutler, N. R. (2016). Sex differences in the psychopharmacological treatment of depression. Dialogues in Clinical Neuroscience, 18(4), 447-457.
Vega-Rivera, N. M., Fernández-Guasti, A., Ramírez-Rodríguez, G., \& Estrada-Camarena, E. (2013a). Acute stress further decreases the effect of ovariectomy on immobility behavior and hippocampal cell survival in rats. Psychoneuroendocrinology, 38(8), 1407-1417. doi: 10.1016/j. psyneuen.2012.12.008

Vega-Rivera, N. M., López-Rubalcava, C., \& Estrada-Camarena, E. (2013b). The antidepressant-like effect of ethynyl estradiol is mediated by both serotonergic and noradrenergic systems in the forced swimming test. Neuroscience, 250, 102-111. doi: 10.1016/j.neuroscience.2013.06.058

World Health Organization. (2018). Depresión. Retrieved from: https://www.who.int/ es/news-room/fact-sheets/detail/depression

Xing, Y., He, J., Hou, J., Lin, F., Tian, J., \& Kurihara, H. (2013). Gender differences in CMS and the effect of antidepressant venlafaxine in rats. Neurochemistry International, 63(6), 570-575. doi: 10.1016/j.neuint.2013.09.019 